\title{
TEACHING ENVIRONMENTAL MANAGEMENT COMPETENCIES ONLINE: TOWARDS “AUTHENTIC” COLLABORATION?
}

\author{
SimonBell[simon.bell@open.ac.uk],.AndyLane[andy.lane@open.ac.uk],Kevin Collins \\ [kevin.collins@@open.ac.uk],Andrea Berardi [andrea.berardi@open.ac.uk], Rachel Slater \\ [rachel.slater@open.ac.uk],The Open University,Engineering and Innovation, The Open University, Milton
}

Keynes, MK76AA, United Kingdom

\begin{abstract}
Environmental Management (EM) is taught in many Higher Education Institutions in the UK. Most this provision is studied full-time on campuses by younger adults preparing themselves for subsequent employment, but not necessarily as environmental managers, and this experience can be very different from the complexities of real-life situations. This formal academic teaching or initial professional development in EM is supported and enhanced by training and continuing professional development from the major EM Institutes in the UK orientated to a set of technical and transferable skills or competencies expected of professional practitioners. In both cases there can be a tendency to focus on the more tractable, technical aspects of EM which are important, but may prove insufficient for EM in practice. What is also necessary, although often excluded, is an appreciation of, and capacity to deal with, the messiness and unpredictability of real world EM situations involving many different actors and stakeholders with multiple perspectives and operating to various agendas. Building on the work of Reeves, Herrington, and Oliver (2002), we argue that EM modules need to include the opportunity to work towards the practice of authentic activities with group collaboration as a key pursuit. This paper reports on a qualitative study of our experiences with a selected sample taken from two on-line undergraduate EM modules for second and third year students (referred to respectively as Modules A and B) at the Open University, UK where online collaboration was a key component. Our tentative findings indicate that on-line collaboration is difficult to ensure as a uniform experience and that lack of uniformity reduces its value as an authentic experience. Whilst it can provide useful additional skills for EM practitioners the experience is uneven in the student body and often requires more time and support to engage with than originally planned.
\end{abstract}

\section{Abstract in Portuguese}

A Gestão Ambiental (GA) é ensinada em muitas instituições de ensino superior no Reino Unido. A maior parte dos cursos são estudados em tempo integral em aulas por jovens adultos que se preparam para um subsequente emprego, mas não necessariamente como gestores ambientais, e esta experiência de estudo pode ser muito diferente da complexidade das situações na vida real. Este ensino acadêmico formal ou desenvolvimento profissional inicial em GA é apoiado e reforçado pela formação e desenvolvimento profissional contínuo dos principais institutos de GA no Reino Unido orientados para um conjunto de habilidades técnicas e transferíveis ou competências esperadas de profissionais. Em ambos os casos, pode haver uma tendência para se concentrar nos aspectos técnicos mais manejáveis da GA que são importantes, mas podem revelar-se insuficientes para GA na prática. O que também é necessário, embora freqüentemente excluído, é uma apreciação e capacidade de lidar com a confusão e imprevisibilidade de situações de GA reais envolvendo muitos atores com múltiplas perspectivas e operando com vários objectivos. Com base no trabalho de Reeves, Herrington, e Oliver (2002), argumentamos que os módulos GA precisam incluir a oportunidade de trabalhar na prática de atividades autênticas 
priorizando a colaboração em grupo. Este trabalho relata um estudo qualitativo de nossas experiências com uma amostra selecionada de dois módulos de GA de graduação on-line para estudantes de segundo e terceiro anos (referidos respectivamente como Módulos A e B) na Open University, no Reino Unido, onde a colaboração on-line foi um componente chave. Nossos resultados preliminares indicam que a colaboração on-line é difícil de garantir como uma experiência uniforme e que a falta de uniformidade reduz o seu valor como uma experiência autêntica. Embora possa fornecer habilidades úteis adicionais para os profissionais de GA a experiência é desigual no corpo estudantil e muitas vezes requer mais tempo e apoio para o envolvimento com o planejamento original.

Keywords: group work, distance learning, e-learning, collaboration, participation, Environmental Management.

\section{Introduction}

Achieving authentic group-work experience in an on-line learning environment is problematic. In this paper we describe and review the progress to date of running online collaborative activities within two modules (or courses) in Environmental Management (EM); activities that attempt to replicate some of the competencies often needed by EM professionals working with different stakeholders in group or community settings. To set the context we briefly review EM as an academic subject and as an emerging profession, as well as the particular form of open, distance and e-learning (ODeL) that The Open University, UK (OUUK) operates. We then describe the two modules and our overall approach to teaching, learning and assessment, before going on to outline the nature of, and discuss our experiences with, the online collaborative activities in relation to the existing best practice in online collaboration.

\section{Background}

\section{EM - Generic Skills and Multiple Perspectives}

Defining what environmental managers do, and thus knowing what to teach for environmental management, is not straightforward. This is exemplified by the way jobs are described, by what professional bodies and others expect and by the range and nature of environmental courses and qualifications offered by other higher educational institutions and providers. The discussion that follows relates mostly to the UK but we expect that the complexity it reveals is applicable in other countries.

"The number of organisations registered under the EMAS standard rose by 50\% during the
period 2003-2010, while organisations from EU countries certified according to the
international ISO 14001 standard more than quadrupled in the period 2001-2009. This
indicates that private companies and public institutions in the EU are increasingly engaging
in environmental management." (EEA, 2013)

The past decade has seen substantial growth in the number of jobs or professional bodies with environmental manager/ management in their title across Europe (EEA, 2013). (In the UK there are 3 professional bodies with EM in their title: Institute of Environmental Management and Assessment (IEMA); Chartered Institution of Water and Environmental Management (CIWEM); Chartered Institute of Ecology and Environmental Management (CIEEM)). Equally there is a growing body of knowledge and skills that relates directly to EM that is not drawn from academic disciplines, as set out in the subject benchmark statement from the Quality Assurance Agency (2014), but is reflected in the cognitive and practical skills demanded by these environmental professional bodies up to advanced Accomplished and Authoritative levels (e.g. see the CIEEM Competency Framework Competence Levels, n.d.). This suggests that there is the potential for 
divergence between the skills and competencies taught in Higher Education and those outlined in professional bodies' competency frameworks. In review of these frameworks it can be seen that the technical and specialised elements vary according to the main contexts and expectations of those bodies while the more generic and transferable competencies are similar. Nevertheless the professional bodies all claim to provide an integrated and/or interdisciplinary approach to their frameworks (see CIEEM (n.d.), CIWEM (n.d.) and IEMA (n.d.)). Even so, the impression of the various frameworks, specifically at the lower levels of accomplishment, is a focus on systematic approaches to "follow good practice guidelines" (see CIEEM, n.d.), with far less focus on the more self-reflective, flexible, interconnected approach that uses systemic methods and managing skills in contested and challenging socio-ecological and technical contexts. Such methods and skills have often been argued to be essential for dealing with the relationships between specific disciplines and dealing with the major complexities of human activity systems. This includes the differing wants, needs and perspectives of those involved with complex environmental situations and how those wants, needs and perspectives may be expressed and managed through face to face and communication technologies as variously but tellingly indicated in a host of examples such as Loan et al. (2007), Ganoulis et al. (2008), Newig and Fritsch (2009) and Powell and Osbeck (2010).

We suggest that this demonstrates evidence of two tendencies in the teaching of EM. On the one hand, and most obviously represented in the various competency frameworks provided by the Professional bodies, a concentration of HE Institutions and Professional Bodies on specific, detailed and generic, technical skills; and on the other hand (but less evident in the frameworks) a recognition of the value of "soft" and systemic skills needed to integrate specific disciplines and their related methods in many EM contexts where the multiple perspectives of stakeholders ensures a contested socio-technical and biophysical situation.

It is this latter aspect which has been in part the concern of our teaching and research. In this paper we will assess our experience in facilitating collaboration and cooperation between students engaged in applying systemic skills in EM.

\section{Teaching EM at The Open University}

EM can be complex and messy. As such, it often requires engaging with and collaboration among diverse stakeholders to progress EM situations - a trend which continues to increase. Systems thinking and practice is one such discipline which both tries to represent and to accommodate different peoples' perspectives on particular situations; and equally it is a discipline that has mostly been applied to managing complex or messy situations in which people are trying to take action (Checkland, 1999; Reynolds \& Holwell, 2010); and unsurprisingly has been extensively applied to managing environmental situations (e.g. Seiffert \& Loch, 2005; Ison, 2010; Gundill et al., 2012).

There is a long history at the OUUK of teaching both systems thinking in practice (Bell \& Lane, 1998; Lane, 1999; 2013; Ison \& Blackmore, 2014); of teaching environmental subjects more widely (Weinbren, 2015; p.210) and of applying systems thinking to environmental situations and sustainability (Berardi, 2011; Blackmore et al., 2015) although it is by no means unique in doing so (Karlsson et al, 2000). However, it is unique in that it has largely been doing so through ODeL. Distance teaching (and learning) of practical skills and doing collaborative work, is challenging in many ways compared to most full-time place based settings.

Firstly, the OUUK is founded upon open entry to undergraduate modules and qualifications, that is, without the necessity for prior qualifications. This leads to a very diverse and distributed student body, of mostly mature students (over 25), studying part-time at the same time as 
engaging in some form of paid work, perhaps located in several different countries. Secondly, there may be issues of access to, and confidence in using, necessary information and communication technologies (ICTs) for studying online. This can particularly be the case for some practical tasks, such as being able to create, share and discuss diagrammatic representations of complex or messy situations (a key skill for system thinking and practice - Lane, 2013). Thirdly, for distance learners distributed through time (zones) and (geographical) spaces around the world synchronous and asynchronous activities rely on the appropriate and negotiated use of ICTs - with all the limitations of losing non-verbal clues in communication. Lastly, whereas a classroom based cohort in a traditional university largely involves interactions between a single teacher and a relatively small group of full time students taking one, possibly two, related degrees, a distance learning module at the OUUK has a large population in the hundreds, with students taking the module as one component of different qualifications. Groups of 20-25 students are allocated to a Tutor (also known as an Associate Lecturer) who provides direct tuition and marks assignments that supplements and supports the teaching embodied within the module's multimedia educational resources. This teaching structure and environment provides extra challenges in organising and managing group based activities.

In the past the OUUK did rely on optional face to face tutorials and also access to a one week residential school where students could have extensive involvement in group based activities. However, the geographical and temporal availability and accessibility of such tutorials has diminished in recent years (a point noted with many connotations for module delivery in a recent Newspaper article (Swain, 2015)). Few residential schools are now run due to a variety of student centred and organisationally focused reasons (see Roy et al., 2005; Slade \& Mullett, 2010). Equally, from the 1990s onwards changes in ICT began changing the ways in which distributed distance learners could collaborate both synchronously and asynchronously. Indeed, this technological change has led to many modules being partly or wholly delivered online (Caird \& Lane, 2015) as is the case for the two modules involved here, and with much effort being put into the aspiration of designing virtual activities to offset the loss of similar or related, possibly more authentic place-based activities.

\section{Collaborative group work online and authenticity - some lessons in the literature}

Collaborative working online (whether that is deemed to be authentic or not to actual working practices) has evolved along with the ICTs that support it, although often as part of face to face teaching programmes. Research into what started out as "Computer Supported Collaborative Learning" has looked at both the technological (e.g. see Muuro et al., 2014; Hwang et al., 2014) and educational aspects of it. Our focus is with the educational aspects and the literature provides much detail. In both Module A and Module B we sought to develop effective groups which could deal with complex problem issues. Brindley et al. (2009) look at this noting that:
"There appears to be a strong argument for including small group collaborative learning experiences in online courses. The literature reveals a significant relationship between participation in these experiences and deeper learning as well as the development of learning and teamwork skills.” (p.15)

These authors also note the importance of coherent instructional strategies in the success of such group work:

"Further, well planned instructional strategies that are intended to improve the group learning experience appear to have a number of added benefits, such as helping students to achieve deeper learning and to build their confidence and skills." (p.16) 
A point amplified in $\mathrm{Xu}$ et al. (2015) who sought to understand how students manage group learning activities. Their findings are instructive:

\begin{abstract}
"[...] based on the data from 298 students (86 groups) in United States. Data revealed that, at the group level, groupwork management was positively associated with feedback and help seeking. Data further revealed that, at the individual level, groupwork management was positively associated with feedback, peer-and learning-oriented reasons, belp seeking, and the number of online courses." (p.195)
\end{abstract}

If coherence of instruction and the value of feedback (as both an aid to group work and a virtuous outcome of a positive group working experience) are important (also noted in Rose, 2004) - so are reflections on the experience students have with online collaboration. Baran and Correia (2009) suggest student-led, as opposed to tutor-led, facilitation tends to be favoured by students and can lead to increased student participation and improve learning outcomes. Veletsianos and Navarrete (2015) offer similar endorsement, noting in their study using the Elgg online social network that their findings:

"... indicate that learners enjoyed and appreciated both the social learning experience afforded by the online social network and supported one another in their learning, enbancing their own and other students' experiences." (p.143)

Further, Zhu (2012) notes that a student's self-perception of satisfaction with the online experience is a key indicator of the sustainability of an online group work process and concludes that:
"the study indicates that learning with peers may benefit not only the overall individual performance, it may also enhance team performance by increasing the quality of team product. Students can learn to formulate ideas and opinions more effectively through group discussion". (p.134)

At a theoretic level, Medeiros Vieira et al. (2014) point beyond this to the potential for a form of collective intelligence.

Group experience may also relate to the quality of the collaboration process and the evolution of collaboration - following traditional group formation phases (such as those described by Tuckman (1965) and Tuckman and Jensen (1977)) or less conventional models (e.g. see Gersick, 1991). Variations on these experiences are described in Jahng (2012) and he suggests that the traditional model of collaboration may not be the best way to assess online groups. Indeed, student focus may well vary across a range of group exercises. Janssen et al. (2012) state:

"Our analyses show that group members devote most of their efforts to regulation of taskrelated activities. For example, by formulating plans or strategies or monitoring task progress. Group members also engaged in social activities often (e.g., disclosing personal information, joking). Less attention was paid to exchange of task-related information (e.g., asking taskrelated questions) and regulation of social activities (e.g., planning and monitoring the collaboration).”(p.25)

Group learning also has negative impacts on students' experiences of group work. Capdeferro and Romero (2012) identified a core reason for frustration with online work:

"The perception of an asymmetric collaboration among the teammates was identified by the students as the most important source of frustration." (p.26) 
Capdeferro and Romero also noted issues around group organization, lack of shared goals, imbalance in commitment, variations in the qualities of input to the group exercise, differences between collective and individual grades and problems with communication. The instrumentalism of students in terms of focusing on grades rather than the values of collaboration has also been noted elsewhere (Cameron et al., 2009)

The list of benefits and issues outlined above are encouraging and intimidating and clearly a workable design for online learning needs to take into account:

- coherent group instruction;

- application and valuing of formal feedback structures;

- identification of forms of group satisfaction with tasks;

- encouraging discussion and a balanced approach to the range of online tasks;

- avoiding whenever possible asymmetry in group inputs;

- providing support to students (via the Tutor network) when apparent injustices, issues of share of load and contribution of intellectual insight emerged.

These are themes we will return to in considering the development of collaborative work in Module A and Module B.

We should note here that by authentic we build on the work of Reeves, Herrrington, and Oliver (2002) around authentic activity. Authenticity does not only mean genuine and accurate but we also refer to the more philosophic meaning of the word which relates to or denotes an emotionally appropriate, significant, purposive, and responsible mode of human life (working from the Oxford English Dictionary definition). In this context, the ten characteristics of authenticity set out by Reeves et al. (2002) suggest that authentic activities in student learning:

- have real-world relevance;

- are ill-defined, requiring students to define the tasks and sub-tasks needed to complete the activity;

- comprise complex tasks to be investigated by students over a sustained period of time;

- provide the opportunity for students to examine the task from different perspectives, using a variety of resources;

- $\quad$ provide the opportunity to collaborate;

- provide the opportunity to reflect;

- can be integrated and applied across different subject areas and lead beyond domainspecific outcomes;

- are seamlessly integrated with assessment;

- create polished products valuable in their own right rather than as preparation for something else;

- allow competing solutions and diversity of outcome.

(Reeves et al., 2002; p.564)

Clearly there are overlaps between these ten characteristics and the six themes we have already identified in the literature. Key to the ten points on authenticity is the inclusion of real world experience. Indeed, the module focus on EM in domestic, organisational and community contexts provided flexibility for developing teaching materials covering a range of topics, but most importantly we believed it to enable a connection between EM and the students' own life and possible work experiences. Everyone has some experience of EM in domestic situations (however diverse); everyone has some engagement with at least one organisation at some level; 
and everyone can relate EM to some form of community context as shaping the places where lives are lived. These lived experiences for mature students will be greater than for students in universities where there is more reliance on abstracted teaching of EM as a mostly scientific or technical subject, set apart from the students' limited lived experiences.

\section{The OUUK's Environmental Management Modules}

The focus of this paper is on the experiences and perspectives of students, supplemented by those of Tutors, of collaborative activities within two related modules dealing with environmental management studied at the equivalent of the second and third year of a 3 year honours degree (namely Module A and Module B respectively). These two 30 credit modules are core components of a 360 credit BSc in Environmental Management and Technology; but they also have been optional modules within a BA in Environmental Studies, a BEng (Bachelor of Engineering) and also within the OUUK's unique BA/BSc Open degree whereby students are free to choose which modules they take for each level (equivalent to year) of study. Furthermore, as students can choose their study intensity to suit their own situation, some will only be studying one module at any one time while others may be studying two or rarely three at the same time.

The design of the modules was based on four principles:

1. That the students have different work and life experiences to brings to their studies.

2. That the teaching and related learning should be online as much as is possible.

3. That EM would be taught in a manner linking conventional EM approaches with systemic teaching. This is a significant topic in itself but by this we refer to teaching which is student-centred, relational, emergent, adaptive, appreciative of multiple perspectives on any given context, collaborative and integrating diverse communication tools including diagramming and self-reflection. By this means we sought to reinforce the systemic nature of EM concerns (the impact of ICTs on teaching and learning diagramming in these two modules is primarily reported in Lane (2017)).

4. That EM teaching needs to enable and facilitate students to work in groups - recognising that contemporary and future EM is increasingly defined by collaboration and often needs to be community facing if it is to be successful.

The rationale for group work in EM is well established with many examples of collaborative processes providing diverse and serendipitous outcomes as well as more formal and planned results (for example see Berardo et al., 2014).

The two modules have a similar structure and philosophy as well as approaches to teaching, learning and assessment. The 300 hours of study time for each module is broken down into three blocks of 60,120 and 120 hours respectively, with the modules running for nine months starting in October. The first block looks at issues related to EM at the domestic or household context; the second deals with EM within organisations; and the third covers EM within community settings. While we teach conventional EM approaches such as life cycle analysis, each module uses systems thinking and practice, including the use of diagramming, as a key toolset alongside an action learning model. (The action learning model is based on the insights of Kolb (1984) and this involves groups working through a cycle of reflecting on past action, considering the nature of the current task, modeling potential means to proceed, acting and reflecting again. The action learning cycle has been a major theme of systems teaching at the Open University for over four decades.) Throughout each block there are a number of online activities, many of which include producing diagrams and sharing them within the tutor group, and at the end of each block there are tutor marked assignments (TMAs), which also require the inclusion of diagrams. The third block, the focus of this paper, requires smaller sub-groups within each tutor group to spend 6-8 
weeks on a group activity that informs the End of Module Assessment (EMA) (while the activity is done in groups, students produce individual Assignments in the EMA but have to reflect on the group process).

Our pedagogical intent was to broaden the emphasis from a singular focus on teaching of knowledge (text based, from teacher to student, limited interactivity) to the learning of skills (online, multimedia, activity rich, collaborative, appreciating others' perspectives, different responsibilities taken up in group work) in order to give students the opportunity to appreciate and gain insight into the systemic nature of EM situations and thus the role of environmental managers. Some of these skills are generic to many modules but our concern with developing an appreciation of systems approaches to EM placed more emphasis on engaging with multiple perspectives and our aim of authentic collaboration which we explore in later sections.

In Module A these contexts of EM were focussed on in terms of domestic energy use and food; organisational concerns with life cycle of IT equipment and also transport; and community issues relating to management of water. In Module B, the same structure was in place, but this time focussing on personal environmental auditing in the domestic context; and then using the example of Heathrow airport to explore how organisations innovate in EM of buildings; and EM of noise in the community.

Our research experiences in diverse areas of EM have convinced us of the critical significance of collaborative group work, both with people you know and often people you do not know, as part of contemporary approaches to EM situations. Group work or working with diverse people as if a group for a defined time and purpose is a key part of professional practice to enable learning about and integration of diverse ideas, experiences and perspectives on situations in order to manage them more effectively. It is also a key aspect of participatory imperatives in many environmental situations where stakeholders have to be formally or informally consulted about or involved in shaping plans and decisions. Leading on and facilitating such participatory activities is an important skill to have (authorities are numerous but see for example O'Faircheallaigh, 2010).

In a module setting, by group work we mean an online collaboration between members of the same tutor group. This is more than posting/replying to messages (e.g. see Peters \& Hewitt, 2010) and includes: careful reading of others' work, purposeful pursuit of shared meaning, asking difficult questions, on-going assessment of what the group does not yet understand, open acknowledgement of confusion etc.

The specifics of the group work in each module were designed to have real world resonance and incremental (from Module A to Module B) relevance to the student.

In Module A the group work was focused on water issues and community engagement. Taking a recent project based on the island of Malta as an illustration and the participatory approach Imagine (as illustrated in Bell and Morse, 2003) as the community engagement approach, students were asked to co-lead on one of four collaborative Events which represented each of the four stages of the Imagine process (The Imagine Method is an evolved method, designed specifically to engage local community in EM initiatives (see for example Bell et al., 2013). Furthermore Imagine lends itself to the systemic teaching pattern of the Open University conforming to an action learning cycle.). The project which they were to work on was very similar to the Maltese example being based on an actual project in Almeria in Spain which was completed in 2012. The leadership expected from the students in this case meant taking a working brief for one of each of the four stages of Imagine and then helping group members to work through the series of tasks each stage required. As each sub-group comprised around ten students, each Event would 
have 2 or 3 leaders. Part of the assignment for this stage of the module was to report back on the leadership results and experience.

In Module B the module team wanted to increase realism and relevance further to the students. Taking airports and the wide range of community environmental impacts which they produce as the basis of the group work, the students again worked in sub-groups of around ten individuals. In Module B the focus was on facilitation rather than leadership. The shift was to facilitate others in their understanding of the ramifications of group / community work in a complex area using London Heathrow airport as a case study. This was supported by collaboration between the module team and the BBC which produced a three-part documentary called "Airport Live" at the airport in 2014. Many hours of footage from this programme and commissioned interviews with major airport and community figures helped to increase the realism and relevance of the various environmental issues emerging from the airport context. A key value of the London Heathrow case study was the generic nature of many of the environmental issues involved and the immediate and personal experience most of our students have of airports.

The group work in both Module A and Module B was developed towards the end of the second Block, providing time for students to become familiar with their sub-group in Block three. In all cases, a Tutor for each student group allocated them into two sub-groups making about 20 subgroups on Module A and 12 sub-groups on Module B. The Tutor is assumed by the end of Block 2 to have a reasonably intimate understanding of the 20 or so students under their tutorage. The two sub-groups are expected to include a cross-section of the abilities, tendencies and capacities. The expectation of the Module Team was that in the early stages of the group work the Tutors would facilitate the sub-groups by pointing them towards the various on-line resources prepared for them. Experience from previous modules and confirmed from the earlier presentations of Module A and Module B was that the sub-groups would increasingly become autonomous to the extent that the various tasks of the Block could be accomplished with minimal input from the Tutors at later stages.

The student numbers for the presentations reviewed are set out in Table 1.

Table 1: Module student numbers and retention

\begin{tabular}{|c|c|c|c|c|c|}
\hline $\begin{array}{l}\text { Module } \\
\text { and Pres }\end{array}$ & $\begin{array}{c}\text { Student } \\
\text { Numbers at } \\
\text { Start of Pres } \\
\end{array}$ & $\begin{array}{c}\text { Student } \\
\text { Numbers at } \\
\text { End of Pres }\end{array}$ & $\begin{array}{l}\text { \% Dropped Out } \\
\text { by end of } \\
\text { module }\end{array}$ & $\begin{array}{c}\% \text { Dropped } \\
\text { out before } \\
\text { Block } 3\end{array}$ & $\begin{array}{c}\text { \% Difference } \\
\text { from Block } 3 \text { and } \\
\text { total }\end{array}$ \\
\hline $\begin{array}{l}\text { Module A } \\
2014\end{array}$ & 283 & 202 & $28.62 \%$ & $22.26 \%$ & $6.36 \%$ \\
\hline $\begin{array}{l}\text { Module A } \\
2015\end{array}$ & 272 & 189 & $30.55 \%$ & $24.63 \%$ & $5.92 \%$ \\
\hline $\begin{array}{l}\text { Module B } \\
2014\end{array}$ & 135 & 103 & $23.7 \%$ & $21.48 \%$ & $2.22 \%$ \\
\hline $\begin{array}{l}\text { Module B } \\
2015 \\
\text { Totals/ }\end{array}$ & 160 & 117 & $26.88 \%$ & $20.62 \%$ & $6.26 \%$ \\
\hline $\begin{array}{l}\text { Overall } \\
\text { averages }\end{array}$ & 850 & 611 & $27.4 \%$ & $22.3 \%$ & $5.15 \%$ \\
\hline
\end{tabular}

Data sourced: Quality Enhancement and Learning Analytics, LTI portfolio, Module Activity Charts 2014-1015, The Open University

As can be seen, the study involved around 611 students as there had been significant drop out prior to Block 3 where the research was undertaken. 
An observation that can be made from the data is that the drop-out rate associated with the group work Block which occurs about a third of the way through the module (on average around $5.15 \%$ ) is not as great as the drop-out rate associated with that prior to the Block (on average around $22.3 \%$ across the modules).

\section{Study Method}

The research described in this paper is on-going and our observations and conclusions are, at present, subject to revision. The method applied in this paper is qualitative sampling, taking on board Yin's maxim that:

"Doing qualitative research means understanding that it is a craft, marked by the challenge of doing original research and pursuing three important objectives: transparency, methodic-ness and adherence to evidence" (Yin, 2016; p.36).

If qualitative research requires craft skills in face to face research (as emphasised in the work of action researchers (e.g. see Chambers, 2002)), it has a further range of complications for on-line research - particularly in terms of what Yin refers to as key features of qualitative research (meaning in people's lives, representing perspective, attending to real world context, contributing explanatory insights and the relevance of multiple sources of evidence). Clearly, researching an online community imposes limitations on the quality of evidence derived from observation at distance and, in an attempt to address such concerns we have adopted a longitudinal assessment seeking what Yin refers to as overarching concepts to organise our study.

From August 2014 to May 2016 the module teams have (with assistance from in-built Open University evaluation processes) monitored and sampled the narratives emerging from the group working process and experience in Module A and Module B. Members of the module teams monitored the student online forums over the 30 weeks of the module presentations, (October to May, 2014 - 2015 and 2015 - 2016) paying particular, but not exclusive attention to the student forums provided in the Virtual Learning Environment (VLE). Each student has access to eight forums in each module (café, the three Blocks, Individual Tutor groups, Sub group forums for group work related to Block 3 and End of Module Assessment) and there were roughly 400 students on the two modules in each of the annual presentations. The entire population was monitored on a daily basis and all forum inputs were read.

What follows is a thematic analysis of qualitative data that we are able to purposefully sample from the very large number of forum posts, emails and open ended survey responses related to the normal running of the modules as well as qualitative data gathered specifically for a separate study on the use of diagramming within the two modules (Lane, 2017). Forum contributions were specifically assessed for themes which were thought likely to impact on the authentic experience of EM group work (features previously noted in the work of Reeves). The research team did not wish to impose their pre-conceived concepts of such themes but rather waited for themes to emerge as clusters of linked and like-minded posts in the forums. This Eductive approach (to be distinguished from inductive or deductive, Eductive: "to draw forth") is consistent with many of the themes of the Action Research and Co-operative enquiry forms of qualitative assessment (e.g. see: Reason, 1994; Moggridge \& Reason, 1996; Bargal, 2008). This qualitative data relates to all completed presentations of the modules and not those happening at the time of writing (from February 2016 to February 2017).

A plethora of items emerged but, at a high level of abstraction our findings resulted in three themes or overarching concepts as emergent meta-issues specifically arising in the process of Block 3 group work over the two modules. These overarching concepts concern: 
- the practicalities of online group work;

- relationships within online group working and

- the value of online group working.

In the next section we review each of these in turn, making use of student quotes to exemplify specific points.

\section{Findings to Date}

Our analysis is primarily concerned with student reflections on group work in Block 3 of Module A and Module B. To emphasise the impact of group work on online communication it is important to recognise that group interaction as represented in forum activity noticeably peaks as students begin the group work. Figure 1 and 2 show the increase in VLE activity for a module which contains group work compared to a more conventional module which does not make use of group work. The data is from the $2014 / 15$ presentation.

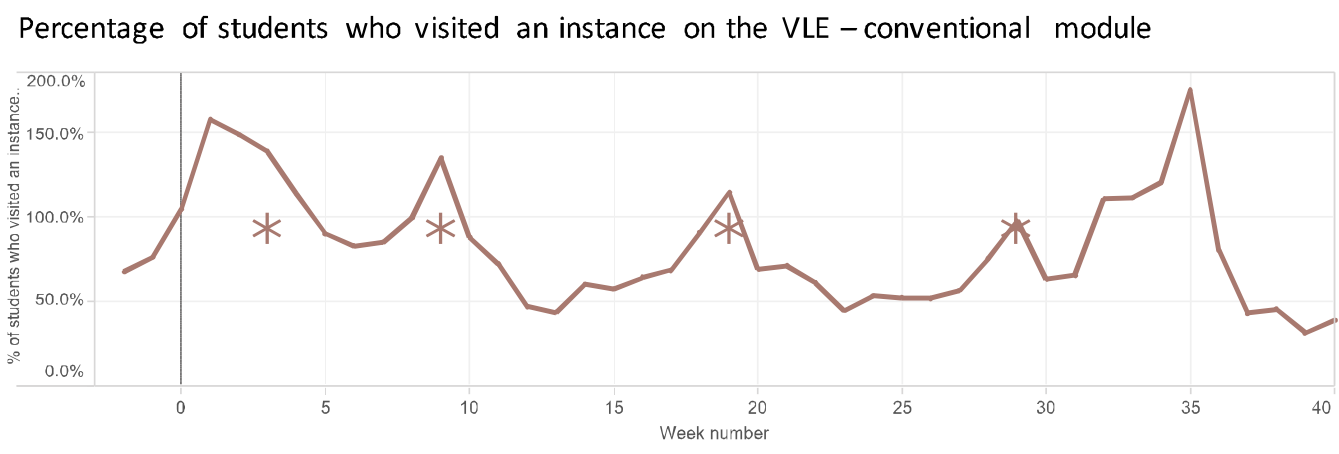

Percentage of students who visited an instance on the VLE - group work module

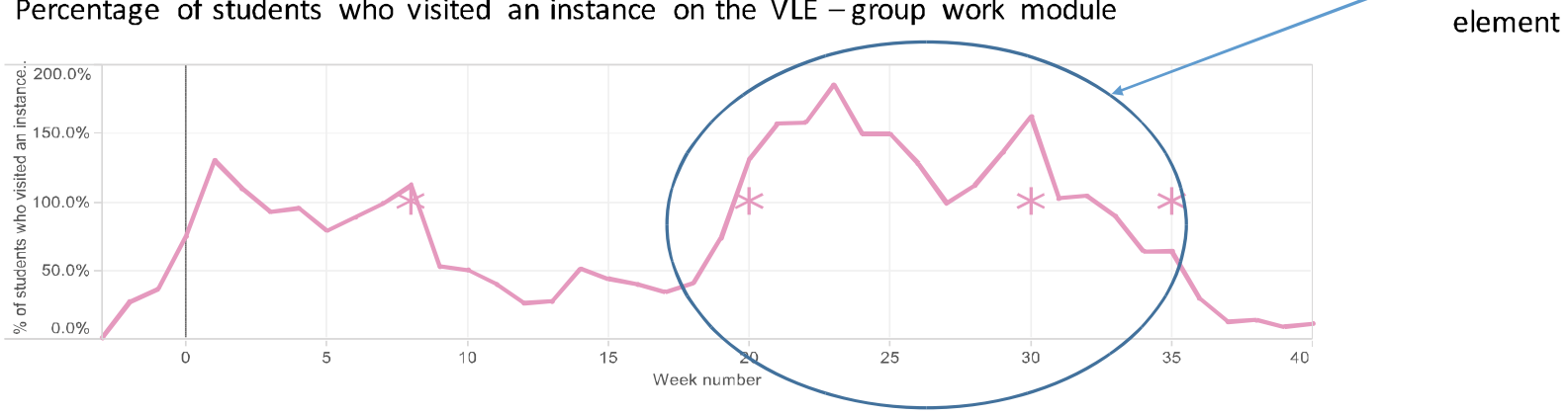

Figure 1. Graphs of impact of group work on VLE activity - comparing non group work module to a module which has group work

While the focus for this analysis is student reflections on collaborative working in small groups, it has to be acknowledged that these perceptions are influenced by the nature of the task as set in the philosophy of the modules. We can point to evidence in both modules that the overall teaching and activities conform to the ten characteristics provided by Reeves et al. (2002), nevertheless, students had differing views, for example, on the relevance and value of systems thinking, of diagramming as a tool or technique used within systems thinking and practice, and of both as being useful for EM as a subject:

"Systems thinking was more difficult for me than environmental management. I found the diagrams straightforward to draw, and I understood what they represented. But what took time and effort to master was applying the module's systems thinking approach to environmental management."

"I found it quite difficult at times to know what the course wanted. I thought at times the course didn't know itself what it wanted, whether it wanted to be sort of technical in terms of 
the environmental action plans and LCAs [Life Cycle Analyses] and what have you, and the technical side of the various systems diagrams or whether it wanted more of the what I call the flowery waffle language in terms of thinking about thinking and putting honest philosophical viewpoints across."

These comments underline the additional difficulty for students taking the modules, the practical and intellectual challenge of applying a systemic approach to EM whilst making use of diagrams and group work. Each might be considered to be a challenge to conventional face to face EM teaching. Combined in online modules they can be expected to provide combinatorial outcomes which may prove tricky to separate.

What follows is a segregation of examples of student responses in line with the three main overarching concepts dealing with the perceived practicalities of the modules, understanding relationships within groups and assessing the value of the group working activity in both modules.

\section{Practicalities of Online Group Working}

The experiences of students in running the various Events and taking particular roles was influenced by many things. The first of these was their previous experience of group working in any form:

"I would say the group work [is most enjoyable] because the first couple of blocks were very new to me and I didn't do quite as well as I expected to do in terms of the marks of the TMAs although it was a bit of a learning curve for me. I learnt a lot from those but the group work was much more enjoyable because I am quite used to working within teams and also leading teams so a lot of it came fairly naturally, especially some of the personality types."

A second issue was about preparation and catching up with the workload:

'Thanks for pushing on with the workload, I appreciate what you're doing. If you don't mind, would you please copy me in on what you've done so far. So far I haven't caught up with the reading to week 3, which means I don't understand what you're doing yet but I hope to be up to speed by the weekend."

Part of the reason for the need to catch up was balancing workload on this module with other modules and within an already (often) congested life. Many students were taking more than one module at a time and this can cause significant problems in terms of study time. The theme of workload relating to studying multiple modules was to recur over the group work Block. Another catch up message is on the same theme but looking forward to Event 2 in week 5:

"I think we are close to being on track at the moment I have a day off on Thursday in which I will dedicate the whole day to event 2!! I've finally caught up on my other assignments so all eyes on this one for the future!"

Another practical difficulty was that some students found it hard to participate in the group work. The reasons varied between other commitments, being in places remote to the other students (time zone) or being away from internet connections. Here is one comment:

"Hi I will continue to sit on the outside looking in because I have had so little involvement and I feel I cannot justifiably get involved with things at this stage not having gone through the entire process. However I hope you do not mind me contributing the occasional comment. I think X's summation is spot on; ....." 
This contradictory lack of practical commitment yet at the same time evidence of desire to commit was often repeated by different students and could be seen as part of the work achieved by Block 3.

This contradiction over commitment might be because the process of Block 3 was a change from many students' previous experience of distance learning. This was made evident in a number of complaining posts:
"it is difficult for all of us to be around at the same time - this course doesn't really suit the normal OU study methods for students who have families and work. At present $X$ is terminally ill, so in the last week I've not contributed anything. To catch up - simply revien and comment on events 1 and 2 then anyone who hasn't facilitated yet need to volunteer to facilitate at event 3 . The rest of us will be around to belp."
"this is very much a module where you have to be bang up to date with it virtually every week a) because of the amount of material in it and secondly because of the amount of group work, which when you get to the group work stage you need to do, the time tabling of the group work. is very very tight and our tutor acknowledge that, which I think was a good point to make right at the outset, that you haven't go much time to do this and when you are doing it by distance learning that makes it even more difficult."

The Blocks were written assuming that students would have space to stand back and not be engaged in all aspects of all weeks. But, if not all members of sub groups participate and life events catch up, then clearly students can find themselves under considerable pressure.

A further practical issue was the limitations of ICTs:

"We, our group, approached this from the view of asynchronous communication, in other words we communicated our ideas and thoughts on the work that we had to do. The tasks were set by adding threads to posts. This to me is a very unwieldy way of doing this particular kind of work. It is almost as if what you are trying to do is... what you are trying to do with environmental management in this particular exercise is that you are pretending that the students are to some extent the stakebolders in this scenario. For the communication to be effective you need to be able to talk to people synchronously. In other words at the same time. I found the whole thing became very disjointed; it was very difficult to keep with people's thoughts or the thread of other people's thoughts in context which was actually vital."

\section{Relationships within Online Group Working}

Related to the practical difficulties that might inhibit students' engagement in and with the group working activities is how different students viewed their fellow students in the group. The role of the Tutor, their e engagement with the Events and with support for the sub groups was also a recurring theme. In one presentation, a Tutor resigned mid-module and the implications of the disengagement prior to and following the resignation is particularly clear in that Tutor's sub groups' dynamic. They found it hard to jell in the first place and subsequently were constantly chasing to catch-up, led by one or two particularly committed individuals.

One Module B student - a member of the group which had Tutor issues - provided the following excellent, amusing and telling Rich Picture and description of the experience - See Figure 2 . 


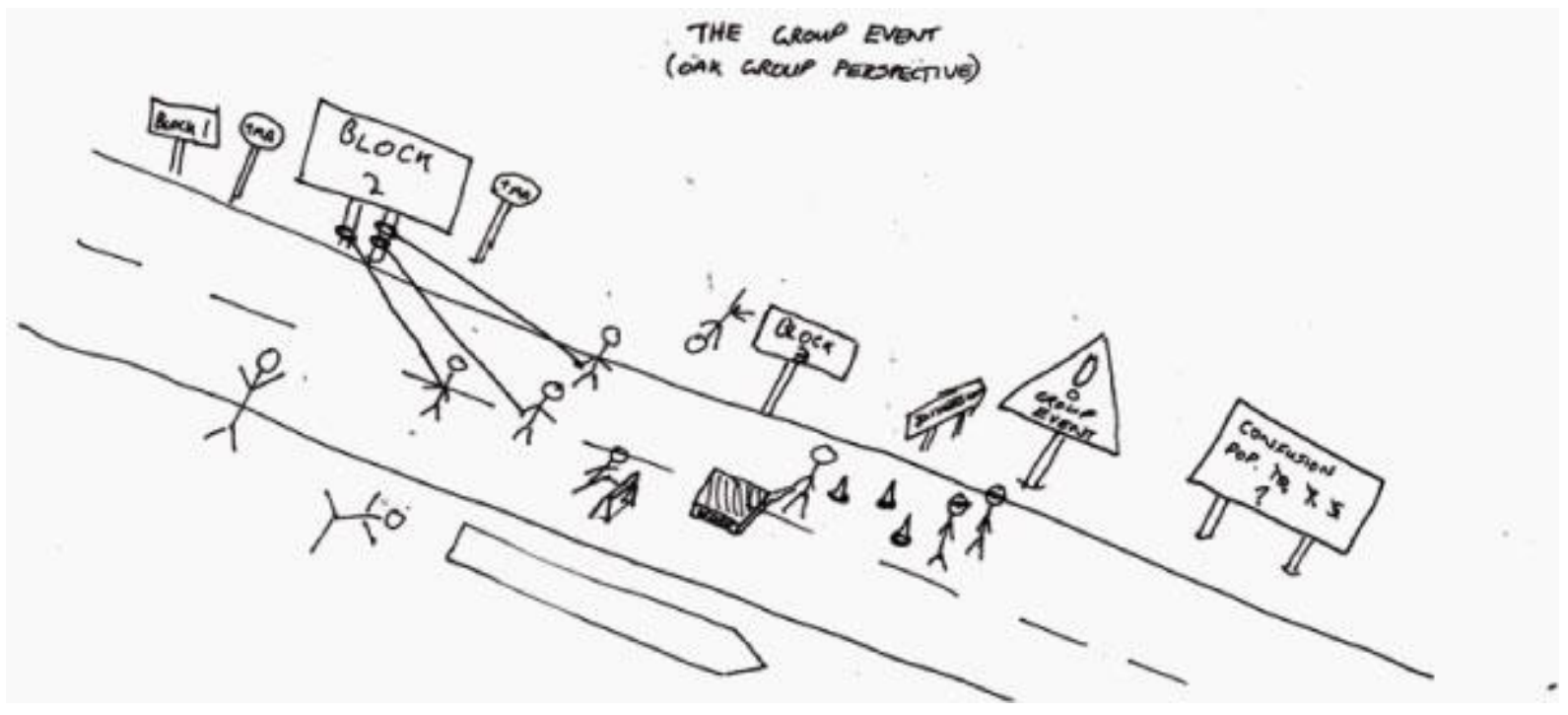

Figure 2. Student Rich Picture of the Module B process

"We're all on the Module B road. Some have fell by the wayside: some are tied to the huge volume of work in block. 2 while others are negotiating obstacles around work/personal commitments and technical problems. While all this is going on the ones who've reached the 'group event' sign have absolutely no idea that nobody's following them."

Clearly the issue of who is actually in the sub group and who is carrying the load of the work is an anxiety. Module texts make it clear that a positive module outcome can be achieved even when issues develop in the sub group but this is an on-going concern thread and something the Module Team needs to consider further. And yet some students in other groups had more positive and supporting perspective. For example, a very late comer to a sub group received this comment:

\begin{abstract}
"Sorry to hear about your difficulties. Judging from the lack of recent input I think our work is done here; time to move on to the TMA. Everything we did was kept here, on this forum (we did not use any of the other tools) and therefore the entire process can be followed in chronological order. All you should need to complete TMA 3 is there, including all the debate and conclusions and the various outputs. There were only 2-4 people sporadically available throughout (very occasionally up to 6), so this lack of numbers meant that all the facilitators contributed to the debate and tasks (rather than remaining impartial) and the overall facilitation was supported by us all. The process was overall a great success, a good team, I believe we all enjoyed it."
\end{abstract}

The importance of the forum as the mechanism and place to archive the work of the group is clear. The power and ability of this small group to sustain its work load and an empathic willingness to share are also notable. The final, positive message despite the lack of engagement by some students is also interesting:

"I have felt disappointed at times with the way we seemed to have been left to our own devices on line at different times but really this is what a remote community or on line debate is about. Parts of events I particularly enjoyed was drawing rich pictures and influence / spray diagrams. I found contribution to debate a real struggle. Honestly this course has helped me a lot at work, as I stopped getting frustrated and think of the bigger picture and others point of view a lot more." 
"I enjoyed looking at others work to get ideas to aid my own diagrams, and I was happy for people to look at mine and gain the same insight."

"I found this very beneficial often alleviating any doubt relating to my understanding of the course requirements. More importantly during group work provided discussion opportunities and was essential in reaching any consensus.”

This spirit of cooperation and inclusion was wide felt and often repeated among the groups and is evidence of the spirit of the facilitation needed in Block 3. This continued even with people emerging from the online shadows and joining groups effectively when the group work was finished.

When the group work progressed well it elicited high praise of the relationships formed:

"Your skills in presenting our collective thinking has again proved invaluable and provides an interesting insight into each of our thinking of the issues and tasks and how we perceive them in the grand order of priority."

"Here is to a big celebration for all of our efforts. It has been wonderful working with you. I think we have developed a great bond and energy. For me, this has been the strongest link I have had with fellow students over my 5 years of OU study."

Again:

"I have never experienced such bonding within a group over my 6 yrs with the OU, even when the courses had monthly face-to-face tutorials. You have all been such great people to work with and to get to know. I have really enjoyed this last two months with all the challenges that it has presented to us and the feelings of satisfaction as we conquered them along the way. I would really like to keep in touch and would definitely like to make our airport meeting reality."

But equally there were some who were much less happy with their experiences of relationships in online group working:

"The sharing diagrams with fellow students is a very good idea, but of course is only as good as the students that take part. I cannot say that this vehicle assisted my studies particularly, because really I didn't receive much feedback during the module from other students. If I'm bonest I would say that my sharing of diagrams tailed off during the module, due largely to lack of any feedback. So yes it's a great idea, if we can get students to participate more fully."

"sorry, but really didn't enjoy the student interaction aspect of this module. I think we were unlucky as a group for Block 3 and some of us found that it actively bindered our studies and actually put the outcome of TMA 3 and the EMA at risk due to either the late submissions or lack of submissions from other students. I could see that it would be good if it worked though re: different insights but unfortunately, for me, it just didn't."

Further study would be needed to fully understand the dynamics behind any particular group's perceived "failure", but the extent to which any online group is able to develop a shared identity and sense of responsibility to each other seems to be central to success. 


\section{Value of Online Group Working}

The value of online group working has already been touched upon above. There appears to be two parts to this perceived value. The first part is to do with the relationships and ways of achieving a group task:

"I am enjoying participating in these events in any capacity, it's fantastic that we are all working as part of a great team despite the lack of tutor support! Absolutely fine by me that you are assisting in our progress throughout these tasks!"

"I found it extremely belpful to share diagrams with students with which I was participating in collaborative exercises. Eventually I was sharing diagrams in online forums and chat rooms with my collaborators, whether called for by module activities or not, as this helped to focus discussion and distil group understanding of the topics at hand."

The second part is to do with appreciating how the online student group activity could replicate doing it for real and how it is part of EM practice:

"I enjoyed the group work as I felt it simulated as closely as possible diagramming in a real situation. I didn't appreciate until the 'water stories' how diagramming can convey information to a wide group of people, enabling them to work together."

"However by the time we got to the group activity I could really appreciate the benefits of rich pictures as a way of making sense of an environmental management situation. The way we pulled our individual rich pictures to produce one collective vision was invaluable throughout the task."

One of the Tutors summarised these key issues of gaining value from the online group exercise and the module as a whole:

"1. Active ... students are interested in taking the process further somehow with tutor/ course team members. Some students want to actually visit Heathrow and create further connection with us in this process -dates in August have already been proposed! There seems to be an interest in a 'space' where post ... students can continue a pragmatic discourse on the transformational aspects of being an 'environmental manager.'"

'2. I am personally looking at the theme of an 'environmental manager' ... 'coming out' ... Addressing Wicked problems and coping with integrating multiple new personal discoveries about the Self/ competencies. I have noticed so many transformations/ transcendences of individuals via [the module] ... 'a coming out' that I don't think I have experienced else where, so rapidly or radically, even magically ... individuals letting go of certain masks and personas, ways of being in order to become. I think it would be valuable to discuss this unique space created by [the module] ... it has wider implications."

An implication is that the modules have, for some students at least, been experienced as different, innovative and career/life enhancing, but clearly the journey was not easy or even.

\section{Discussion and Conclusions}

At the outset of this paper we noted that achieving authentic group-work experience in an on-line environment was problematic. We also noted that the EM context provided for specific challenges both in terms of harmonizing teaching with professional requirements and providing students with both generic / conventional skills and more advanced, systemic understandings. Prior to setting out our experiences with Module A and Module B, we had noted in the literature 
that authentic online learning should be based in real world experiences. It should also take into account coherent group instruction, application and valuing of formal feedback structures, identification of forms of group satisfaction with tasks, encouraging discussion, balancing the range of online tasks and avoiding whenever possible asymmetry in group inputs. The experiences of students described above tend to endorse and amplify most of these points.

A significant student concern seems to be linked to what we can think of as polarisation of the student body towards the module and aspects of it, including the group work. This polarisation is seen in the comments of the students who stayed with, and completed, the module and their comparison of the on-line modules to other OUUK modules which are print based. The polarity extends further. Students drew a distinction between well-established and well understood modules of print plus some limited online distance learning combined using a more knowledge based, instructivist approach compared with the fully online modules included in this research which make use of a more skills based, constructivist approach and which also have substantive collaborative activity combined with the technique of diagramming. Despite these challenges to the on-line EM modules both also received some students' satisfaction at co-learning with others, including two key transferrable skills - group leadership and facilitation - and a richness in learning experience which one Tutor in particular found unique.

Looking beyond this polarisation of views around the module presentations as a whole, a number of observations can be made regarding the responses of students to systems diagramming and the wider group-work experience.

In so far that diagramming is a key feature of the group working students are equally polarised between those that hated them and those who found them useful. Even those finding them useful noted that they provided a demanding workload, that the use of ICT was more a hindrance than a help in undertaking this skill and that face to face working would be preferable. These same issues extended into how well and how helpfully fellow students and particularly their tutors could comment and give feedback on their diagrams (tutors also remarked on the challenges involved in marking and commenting on diagrams in assignments).

Similar trends are apparent in student responses to the group work.

On reflection, five observations emerge as a conclusion (so far) to the experience of Module A and Module B in terms of the group work component:

Firstly, the importance of the tutor and clear instructional strategies (as noted by Brindley et al., 2009) to the student participative experience is vital. Tutor engagement with groups seems key to motivation, inclusion and quality experience. This raises an issue about the changing role of the Tutor. In conventional distance teaching this role is centrally concerned with assessment. Student pastoral care is very much a supplementary and minor aspect. With on-line modules the role of the Tutor is transformed by potential for real-time and asynchronous relationship building. The Tutor has a real capacity to "make" the module. Outward going, charismatic Tutors who are familiar with VLE technologies can increase student retention, can ease learning difficulties and create a buzz around learning. This potential in the Tutor role is not really understood or accommodated in current training.

Secondly, in much of our teaching module teams tend to assume that no other modules are happening at the same time. It would be useful to look at a way of balancing load between modules being taken at the same time. One of the most continuous complaints in Block 3 was the comment (paraphrased): "I am still trying to finish TMAxx in [other module name]. Sorry I cannot collaborate right now". Improvement might be achieved if module teams intending to 
include group work in their teaching were aware of distinct time periods when module load elsewhere is less acute. However, this would require a degree of control over module selection by students, and detailed control over other module content and timing which is at present simply impossible.

Thirdly, and again echoing Brindley et al. (2009), students certainly provide copious examples of learning by doing, even if they are not aware that they are. The online group work learning process is immersive and even negative experiences are experiences of the process. Often this is consciously understood later in the Block. A good example of this kind of elevated experience is set out in this comment by a student:

"As a very anxious person in general, I was very disheartened to see that group work was part of this course. As more time passes I am finding it easier to communicate with the group and take part in the group work as a whole. As a Co-Leader of the first event I definitely have taken a backseat in comparison to others due to strong personalities, ideas and work. ethics. I felt it quite difficult to do much to drive the group forwards as the ball was always rolling, but always did my best to meet deadlines agreed upon in our discussions and have input when necessary."

If not a regular experience, this reflection - that learning by doing can help a student transcend personal issues and push on to new levels of self-awareness suggests that there are elements of the Module A/Module B model which provide highly fruitful areas for further development.

Fourthly, time to engage with group work. Group work is the core of Block 3 in each module and can take significantly more time than may have been appreciated in the initial module design and the module teams are working on ways to lighten other loads in the Block content and assessment in line with Cameron et al.'s (2009) observation that a focus on grade can reduce quality of learning. Students should have the necessary time to focus on emergent learning qualities arising from experience of group experience. It should be noted that, students studying Module A and Module B are prepared for the group work and, as with Brindley, the group work occurs in the last third of the module "after students demonstrate that they have sufficient mastery of the subject matter" (ibid; p.11).

Fifthly and finally, asymmetry of effort (Capdeferro \& Romero, 2012), is clearly an issue. An urgent area for further module development relates to the need to provide a means whereby a student can know who is contributing to their sub group and initiate processes to ensure that task load is more evenly spread. 


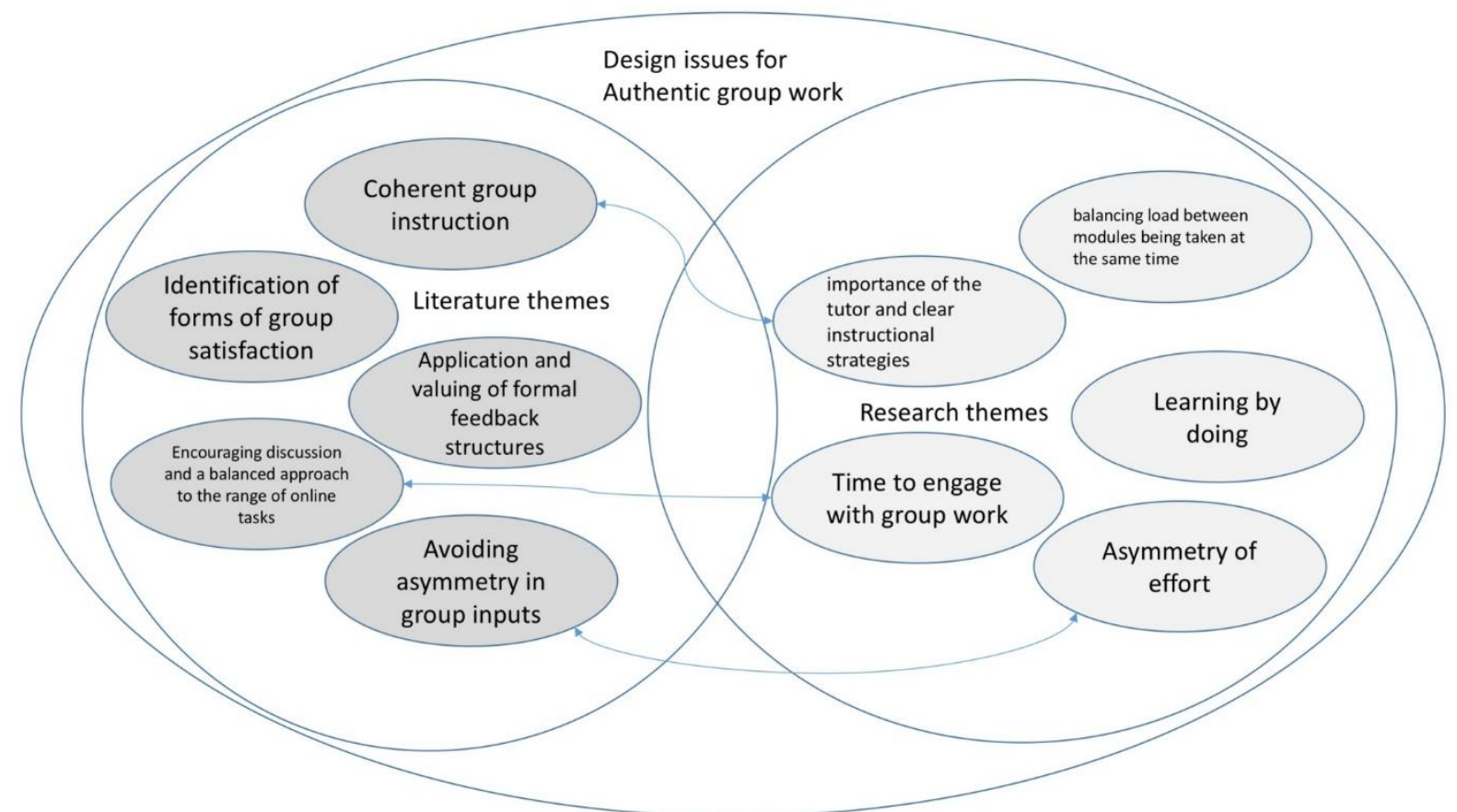

Figure 3. Influence diagram of the design issues for achieving authentic group work

We set out the main themes emergent from the experience of Module A / Module B as related to the dominant themes in the literature on authentic activities in general and collaborative group work online in particular in Figure 3. Our goal remains to provide students with as authentic as possible an experience of EM practice. While we feel that our modules "tick the boxes" for Reeves et al. (2002) ten characteristics for authentic activity, achieving truly collaborative online work is challenging while technical and pedagogic issues remain and, as can be seen from the sets of issues and concerns set out in Figure 3, our work provides some clear overlap (specifically in three cases) and there is considerable room for comparison in all cases.

As both modules progress from inception to maturity (in the University presentation lifecycle) there is pedagogic and methodological potential emerging to improve upon current online module development. In this paper we have seen how issues around practicalities, relationships and values feed into and emerge in concepts of tutor support, module schedule, learning pedagogy, workload and asymmetry of effort. Clearly there is a growing necessity to build into online presentation greater awareness and contingency in terms of these emergent properties.

\section{References}

1. Baran, E., \& Correia, A. (2009). Student-led Facilitation Strategies in Online Discussions. Distance Education, 30(3), 339-361.

2. Bargal, D. (2008). Action Research: A Paradigm for Achieving Social Change. Small Group Research, 39(1), 17-27.

3. Bell, S. (2011). From Sustainable Community to Big Society: Ten Years Learning with the Imagine Approach. International Research in Geographical and Environmental Education, 20(3), 247267.

4. Bell, S., Correa Peña, A., \& Prem, M. (2013). Imagine coastal sustainability. Ocean \& Coastal Management, 83, 39-51. Retrieved November 12, 2014, from http://linkinghub.elsevier.com/retrieve/pii/S0964569113000483 
5. Bell, S., \& Lane, A. (1998). From teaching to learning: technological potential and sustainable, supported open learning. Systemic Practice and Action Research, 11(6), 629-650.

6. Bell, S., \& Morse, S. (2003). Measuring Sustainability: Learning from Doing. London: Earthscan.

7. Berardi, A. (2011). The Challenges of Transformational Learning at a Distance: a year in the life of an Open University learning unit on the environment. LATHE, 5, 135-142.

8. Berardo, R., Heikkila, T., \& Gerlak, A. K. (2014). Interorganizational Engagement in Collaborative Environmental Management: Evidence from the South Florida Ecosystem Restoration Task Force. Journal of Public Administration Research and Theory, 24(3), 697-719. Retrieved from http://jpart.oxfordjournals.org/cgi/doi/10.1093/jopart/muu003

9. Blackmore, C., Reynolds, M., Ison, R., \& Lane, A. (2015). Embedding sustainability through systems thinking in practice: some experiences from the Open University. In L. Wyness, (Ed.), Education for Sustainable Development Pedagogy: Criticality, Creativity, and Collaboration (PedRIO occasional papers (8), pp.32-35). Plymouth University: Pedagogic Research Institute and Observatory (PedRIO).

10. Brindley, J., Blaschke, L., \& Walti, C. (2009). Creating effective collaborative learning groups in an online environment. The International Review of Research in Open and Distributed Learning, 10(3), 1-18.

11. Caird, S., \& Lane, A. (2015). Conceptualising the role of Information and Communication Technologies in the design of higher education teaching models used in the UK. British Journal of Educational Technology, 46(1), 58-70.

12. Cameron, B. A., Morgan, K., Williams, K. C., \& Kostelecky, K. L. (2009). Group Projects: Student Perceptions of the Relationship between Social Tasks and a Sense of Community in Online Group Work. American Journal of Distance Education, 23(1), 20-33. Retrieved from http://www.tandfonline.com/doi/abs/10.1080/08923640802664466

13. Capdeferro, N., \& Romero, M. (2012). Are online learners frustrated with collaborative learning experiences? International Review of Research in Open and Distance Learning, 13(2), 26-44.

14. Chambers, R. (2002). Participatory Workshops: A sourcebook of 21 sets of ideas and activities. London: Earthscan.

15. Chartered Institution of Water and Environmental Management - CIWEM (n.d.). Membership. Retrieved from http://www.ciwem.org/membership/

16. CIEEM (n.d.). Competency Framework. Retrieved from http://www.cieem.net/competencyframework

17. Checkland, P. (1999). Systems Thinking, Systems Practice ( $2^{\text {nd }}$ ed.). London: Wiley.

18. ENDS report, The (2010). Environmental Careers Guide. London. Retrieved from http://www.endsreport.com/reports/ecg

19. European Environment Agency (2013). Number of organisations with registered environmental management systems according to EMAS and ISO 14001. Retrieved from http://www.eea.europa.eu/data-and-maps/indicators/number-of-organisations-withregistered/assessment

20. Fazey, L., Fazey, J. A., Fischer, J., Sherren, K., Warren, J., Noss R. F., \& Dovers, S. (2007). Adaptive Capacity and Learning to Learn as Leverage for Social-Ecological Resilience. Frontiers in Ecology and the Environment, 5(7), 375-380. doi: 10.1890/15409295(2007)5\%5B375:ACALTL\%5D2.0.CO;2 
21. Ganoulis, J., Skoulikaris, H., \& Monget, J. M. (2008). Involving stakeholders in transboundary water resource management: The Mesta/Nestos 'HELP' basin. Water S.S., 34(4), 461-467.

Retrieved from https://www.scopus.com/record/display.uri?eid=2-s2.067649355071\&origin=inward\&txGid=426BF51B75CF30CBC4B61D127E1C1F2F.wsnAw8k cdt7IPYLO0V48gA\%3a1

22. Gersick, C. (1991). Revolutionary Change Theories: a multilevel exploration of the punctuated equilibrium paradigm. Academy of management Review, 16(1), 10-36.

23. Gundill, G., Cummings G. S., Biggs, D., \& Fabricius, C. (2012). Soft Systems Thinking and Social Learning for Adaptive Management. Conservation Biology, 26(1), 13-20.

24. Hwang, W. Y., Kongcharoen, C., \& Ghinea, G. (2014). To enhance collaborative learning and practice network knowledge with a virtualization laboratory and online synchronous discussion. International Review of Research in Open and Distance Learning, 15(4), 113-137.

25. IEMA (n.d.). Skills Map. Retrieved from https://www.iema.net/skills-map

26. Ison, R. (2010). Systems Practice: How to Act in a Climate Change World. London: Springer.

27. Ison, R., \& Blackmore, C. (2014). Designing and Developing a Reflexive Learning System for Managing Systemic Change. Systems, 2, 119-136.

28. Jahng, N. (2012). An investigation of collaboration processes in an online course: How do small groups develop over time? International Review of Research in Open and Distance Learning, 13(4), 1-18.

29. Janssen, J., Erkens, G., Kirschner, P. A., \& Kanselaar, G. (2012).Task-related and social regulation during online collaborative learning. Metacognition and Learning, 7(1), 25-43. Retrieved from http://link.springer.com/10.1007/s11409-010-9061-5

30. Karlsson, R., Nasir, J., Bergeå, O., \& Jonsson, T. (2000). Systems thinking for Sustainable Resource Management in Environmental Management Education. Proceedings of $1^{\text {st }}$ International Conference on Systems Thinking in Management, Geelong, November 8-10, 2000, 282-287. Retrieved from http:// ceur-ws.org/Vol-72/043\%20Karlsson\%20environment.pdf

31. Kolb, D. (1984). Experiential Learning: experience as the source of learning and development. London: Prentice-Hall.

32. Lane, A. B. (1999). Teaching Systems at the Open University: reconceptualising the curriculum by creating meaningful conversations. In A. M. Castell, A. J. Gregory, G. A. Hindle, M. E. James, \& G. Ragsdell (Eds.), Synergy Matters: Working with Systems in the $21^{\text {st }}$ Century (pp.499-504). New York: Kluwer Academic/Plenum.

33. Lane, A. (2013). A review of diagramming in systems practice and how technologies have supported the teaching and learning of diagramming for systems thinking in practice. Systemic Practice and Action Research, 26(4), 319-329.

34. Lane, A. (2017, in press). The impact of technology on the teaching and assessment of 'systems' diagrams in two online environmental management modules. Milton Keynes: Open University.

35. Medeiros Vieira, L. M., Ferasso, \& M. da Silva Schröeder, C. (2014). Connecting Multiple Intelligences through Open and Distance Learning: Going Towards a Collective Intelligence? European Journal of Open, Distance and e-Learning, 17(1), 108-117. Retrieved from http://www.eurodl.org/materials/briefs/2014/Medeiros-Vieira_et_al.pdf

36. Moggridge, A., \& Reason, P. (1996). Human Inquiry: Steps towards Emancipatory Practice. Systems Practice, 9(2), 159-175. 
37. Muuro, M. E., Wagacha, E. P., Oboko, R., \& Kihoro, J. (2014). Students' Perceived Challenges in an Online Collaborative Learning Environment: A Case of Higher Learning Institutions in Nairobi, Kenya. International Review of Research in Open and Distance Learning, 15(6), 132-161. Retrieved from http://eric.ed.gov/?id=EJ1048242

38. Newig, J., \& Fritsch, O. (2009). Environmental governance: participatory, multi-level - and effective? Environmental Policy and Governance, 19(3), 197-214. doi: 10.1002/eet.509. Retrieved from http://onlinelibrary.wiley.com/doi/10.1002/eet.509/abstract

39. O'Faircheallaigh, C. (2010). Public participation and environmental impact assessment: Purposes, implications, and lessons for public policy making. Environmental Impact Assessment Review, 30(1), 19-27. Retrieved July 28, 2014, from http://linkinghub.elsevier.com/retrieve/pii/S0195925509000845

40. Peters, V. L., \& Hewitt, J. (2010). An investigation of student practices in asynchronous computer conferencing courses. Computers and Education, 54, 951-961.

41. Powell, N., \& Osbeck, M. (2010). Approaches for understanding and embedding stakeholder realities in mangrove rehabilitation processes in Southeast Asia: Lessons learnt from Mahakam Delta, East Kalimantan. Sustainable Development, 18(5), 260-270.

42. Quality Assurance Agency for Higher Education, The (2014). Subject Benchmark Statement. Earth Sciences, Environmental Sciences and Environmental Studies. Retrieved from http://www.qaa.ac.uk/en/Publications/Documents/SBS-earth-sciences-14.pdf

43. Reason, P. (Ed.) (1994). Participation in Human Inquiry. London: Sage.

44. Reeves, T., Herrington, J., \& Oliver, R. (2002). Authentic Activities and Online Learning. Quality Conversations: Proceedings of the 25 $5^{\text {th }}$ HERDS A Annual Conference, 7-10 July 2002, Perth, Western Australia, 562-567.

45. Reynolds, M., \& Holwell, S. (Eds.) (2010). Systems Approaches to Managing Change: A Practical Guide. London: Springer.

46. Rose, M. A. (2004). Comparing productive online dialogue in two group styles: Cooperative and collaborative. American Journal of Distance Education, 18(2), 73-88. Retrieved from http://www.tandfonline.com/doi/abs/10.1207/s15389286ajde1802_2

47. Roy, R., Potter, S., Yarrow, K., \& Smith, M. (2005). Towards Sustainable Higher Education: Environmental impacts of campus-based and distance higher education systems. Final Report. Milton Keynes: The Open University.

48. Seiffert, M. E. B., \& Loch, C. (2005). Systemic thinking in environmental management: support for sustainable development. Journal of cleaner Production, 13(12), 1197-1202.

49. Slade, S., \& Mullett, E. (2010). Retention and progression of online global students: a pilot approach. Paper presented at the $9^{\text {th }}$ European Conference on e-Learning (ECEL 2010), 4-5 November 2010, Instituto Superior de Engenharia do Porto. Porto, Portugal.

50. Swain, H. (2015, October 20). This change will be the end of the Open University as we know it. [Blog post] The Guardian. Retrieved from https://www.theguardian.com/education/2015/oct/20/open-university-strike-ou-regionalcentres-moocs

51. Tuckman, B. W. (1965). Development Sequence in Small Groups. Psychological Bulletin, 63(6), 384-399.

52. Tuckman, B. W., \& Jensen, M. A. (1977). Stages of Small Group Development Revisited. Group Organisational Studies, 2(4), 419-427. 
53. Veletsianos, G., \& Navarrete, C. C. (2015). Online Social Networks as Formal Learning Environments : Learner Experiences and Activities. The International Review of Research in Open and Distance Learning, 13(1), 1-13.

54. Weinbren, D. (2015). The Open University; A History. Manchester, UK: Manchester University Press.

55. Xu, J., Du, J., \& Fan, X. (2015). Students' Groupwork Management in Online Collaborative Learning Environments. Educational Technology \& Society, 18(2), 195-205.

56. Yin, R. K. (2016). Qualitative Research from Start to Finish. New York: The Guiford Press.

57. Zhu, C. (2012). Student Satisfaction, Performance, and Knowledge Construction in Online Collaborative Learning. Educational Technology \& Society, 15(1), 127-136. Retrieved from http://www.ifets.info/journals/15_1/12.pdf 